\title{
Papilomas e carcinomas em úbere de cabras criadas no sertão pernambucano
}

Huber Rizzo, Taile Katiele Souza de Jesus, Carla Cristina Moura de Oliveira, Jeferson da Silva Carvalho, Diogo Diógenes Medeiros Diniz, Órion Pedro da Silva, Sandra Maria de Torres, Valdemiro Amaro da Silva Júnior

Departamento de Medicina Veterinária, Universidade Federal Rural de Pernambuco (UFRPE), Recife, PE, Brasil

*Autor correspondente

e-mail: hubervet@gmail.com

\section{Resumo}

Papilomas em caprinos são raramente descritos, acometendo principalmente animais da raça Saanen criados em regiões de alta incidência solar, sendo esse também um fator predisponente para o desenvolvimento de carcinomas de células escamosas (CCE). Foram examinados, em maio de 2016, duas cabras da raça Saanen, lactantes, criadas em propriedades distintas e não contactantes do município de Sertânia, no sertão pernambucano. Apresentavam lesões neoplásicas no úbere, sendo os únicos indivíduos dos rebanhos (total de 185 animais) com esse quadro. Eram criadas em sistema semiextensivo e haviam sido adquiridas há aproximadamente um ano com a presença de nódulos verrucosos, em forma de "grão de arroz", de 0,5 a 1 cm de comprimento, principalmente nos tetos do úbere, com sucessivas fases de progressão e regressão durante o ano. Aproximadamente oito meses antes da consulta, essas neoformações passaram a persistir e a se multiplicar localmente, acompanhadas por lesões ulceradas e crostosas, de 2 a $10 \mathrm{~cm}$, lateralmente ao úbere, infectadas posteriormente por bactérias secundárias. Em um dos animais (cabra 1) foi observado tecido cornificado de $15 \mathrm{~cm}$ de comprimento se projetando na região lateral direita do úbere. Os animais foram submetidos a exame hematológico e bioquímico (fibrinogênio, proteínas totais, ureia, creatinina, AST e GGT), além da coleta de fragmentos das neoformações da glândula mamária, armazenados em solução de formalina tamponada a 10\% para posterior avaliação histopatológica. Quanto à avaliação bioquímica, os animais apresentavam-se dentro dos parâmetros normais, com valores de fibrinogênio no limite superior (400 mg/dL). Hematologicamente, a cabra 1 apresentou leucocitose $(23.400 / \mu \mathrm{L})$ com neutrófila $(16.912 / \mu \mathrm{L})$ e monocitose $(1.390 / \mu \mathrm{L})$, enquanto que na cabra 2 os parâmetros encontravam-se dentro da normalidade. A histopatologia de ambas evidenciou a presença de hiperplasia de camada granulosa com produção exacerbada de queratina, originando projeções epidérmicas típicas de papilomas e proliferações 
de células epiteliais em ilhas associadas a tecido conjuntivo diferenciado em queratinócitos de intensa produção de queratina, levando à formação de pérolas córneas, características de CCE. Além disso, observouse a presença de colônias bacterianas associadas a processo inflamatório subagudo rico em neutrófilos, linfócitos e plasmócitos. 0 quadro corrobora com outros relatos onde a morbidade da lesão no rebanho é baixa, estando associada à raça Saanen e a regiões com alto índice ultravioleta (UV), como em Sertânia, com UV 9, além da maior proliferação da lesão no período de lactação. Os valores de fibrinogênio e de leucócitos observados demonstram processo inflamatório e infeccioso. Pela extensão das lesões, comprometimento da ordenha com o sangramento durante esta, queda na produção de leite e possível disseminação a outros animais, foi recomendado o descarte das cabras. Faz-se importante a realização de exame clínico e quarentena no momento da aquisição de novos animais, evitando, assim, a introdução de enfermidades no rebanho. 